\title{
How International Financial Reporting Standards (IFRS) Improve the Financing of SME's in the Czech Republic
}

\author{
Miluše Korbelová ${ }^{1}$
}

\begin{abstract}
:
The accountancy management inline with the IFRS provides quality and trustworthy information for financial statement users and provides the comparison with similar companies at international level.

The importance of creating the closing financial statements inline with the IFRS grows with the development of cross-border trade, cooperation and competition within the business environment where the prevailing economical element are the small and medium sized enterprises (SME).
\end{abstract}

The support of SME and their bussiness activities at the national and international market is the target of national politics and politics of the EU. To help the international comparison the IFRS for SME and many other programs were created to support the SME funding within the EU. The Czech Republic doesn't allow to assemble and public the closing financial statement inline with the IFRS.

The access to the funds is therefore complicated, the economic indicators show different values when assembling the closing financial statement inline with the IFRS or inline with Czech accounting standards (CAS).

The seven SMEs out of different bussiness sectors focusing on cross-border trade are illustrative of the current situation in the Czech Republic.

Keywords: IFRS for SME, small and medium sized enterprises, SME funding, liquidity, indebtness.

JEL Classification: H2O, H21, M41.

\footnotetext{
${ }^{1}$ Mendel University in Brno, Zemědělská 1, 61300 Brno, lucaa@volny.cz
} 


\section{Introduction}

The basis of the world business is created by the small and medium sized enterprises (SME). It usually represents family business of one or more owners. Their importance for economy is monitored by the Czech Republic as well as by the EU and there is driveto support them. The duty of the state is to provide the public service and this is the main reson for tax collection. Accounting provides the basis for calculation the tax basis. The state regulates accounting using law, notices and Czech accounting standards in order to ease the control and the tax collection management. The complusory chart of accounts and the mandatory stucture of the financial statement is provide by the Ministry of Finance. The ongoing globalisation needs accounting and tax harmonisation, particularly within the EU. International Accounting Standards Board (IASB) published the IFRS for SME with a recommendation for the member states of the EU to enable the enterprises to prepare accounting books and assembly financial statements inline with these standards. The Czech Republic didn't allow this measure for SME.

\section{The goal and metodology of the study}

The goal of this work is to show on actual financial statements, assembled in line with the IFRS and CAS the diffences in the financial indicators used by the financial institutions to consider the solvency of the client in order to decide about a loan or leasing to fund the new investments. Used samle consists of auited financial statements of seven SME's Publisher in the business register. The production od seleected SME's is export-oriented and they either cooperate across the borders or have a foreign owner themselves.

The enterprises give up the current consumption in order to increase the production in future (Valach, 2010; Helisek, 2016). Financial institutions evaluate the enterprise according to the indicators calculated from financial statements and accounting documents in order to consider their abiliti of repay in a sufficient time horizon and to pay back the expenses connected with the external capital - interests, fees and provisions (Giannarakis, 2016; Thalassinos and Liapis, 2014; Thalassinos et al., 2014; Liapis and Thalassinos, 2013; Thalassinos and Kiriazidis, 2003).

In the Czech Republic are accounting units obligated to keep accounting according to the czech law and the CAS. The law prescribes accountint methods and evaluation, the financial statement content, its structure and other particularities ${ }^{2}$. The key purpose of this regulation lies on the unification and easy control performed by tax administrator, particularly for the tax purposes. The content of specific items of the financial statement regarding the quality and quantity is settled via the state regulation. The essential part of the state regulation is the data allocation (in accounting) for the tax purposes.

\footnotetext{
${ }^{2}$ Law n. 563/1991 Code., on accounting.
} 
The international accountancy standards define the conceptual framework. Financial statements are composed by a Balance sheet, a Profit and Loss account, a Notes, a Changes in working capital, and Cash flow. The content, structure particularities are not set by the regulation. The accent remains on the reliable, trustworthy and understandable information for users of financial statements with regard their importance ${ }^{3}$. The way to achive it is up to the accounting unit itself.

Although it seems that both standards adjust the same with the same outcomes, the content is significantly different. The selected items of SME's financial statements were ofiginally assembled according to the CAS and then are transformed into the IFRS format. Necessary adjustments concern the following items:

- Long-term liabilities were converted into the present value

- Long-term receivables were converted into the present value

- Exchange rate gains and losos were excluded (unrealised gains and losses).

To evaluate the solvency of the company to obtain the loan or leasing is showen throught following indicators which are used by financial institutions:

1. EBIT - Earnings before Interest and Taxes

2. Indebtness $=$ liabilities $/$ assets

3. ROE (Return on Equity) - EBIT / Equity

4. Liquidity $=$ current assets/ current liabilities

5. ROA (Return on Assets) $=$ EBIT / Assets

Assets are expresem in their book value.

\section{Problems schema}

\subsection{European Union and the World}

The 95 per cent of all the companies in the world are represented by $\mathrm{SME}^{4}$. Definition of SME comes from the directive ES 70/2001 (Table 1). They represent 99,8 per cent within the EU, where the 92,7 per cent represent the microunits, 6,1 per cent are the small enterprises and 1 per cent avers the medium sized enterprises ${ }^{5}$. In the Czech Republic there are simile proportions of company snes. An important portion on the employment rate and the accounting added value belongs to the Czech SME (Müllerová, Paseková, Hýblová 2010; Thalassinos, 2008; Thalassinos and Dafnos, 2015). According to the EU Small and Bussiness Act (SBA) initiative the number of people employed by SME is 69,6 per cent in the Czech Republic and 66,9 per cent in the EU out of the total number of employed persons.

\footnotetext{
${ }^{3}$ Dvoŕáková D., 2008, Financial accounting and reporting in line with the international standards IFRS, Computer Press, a.s. 2008, IASB, London, International Financial Reporting Standards (IAS - International Accounting Standards, IFRS).

${ }^{4}$ http://www.ifrs.org/IFRS-for-SMEs/Pages/IFRS-for-SMEs.aspx

${ }^{5}$ Data overview SBA 2015, Czech Republic
} 
Table 1: Accountancy units cathegory in line with ES 70/2001

\begin{tabular}{|l|l|l|l|}
\hline Cathegory & $\begin{array}{l}\text { Maximum annual } \\
\text { turnover in mil. } €\end{array}$ & $\begin{array}{l}\text { Maximum balance } \\
\text { sum in mil. } €\end{array}$ & $\begin{array}{l}\text { Number } \\
\text { of employees } \\
\text { (re-count on full- } \\
\text { time) }\end{array}$ \\
\hline Microenterprise & $0-2$ & $0-2$ & $0-10$ \\
\hline Small enterprise & $2-10$ & $2-10$ & $10-50$ \\
\hline $\begin{array}{l}\text { Medium sized } \\
\text { enterprise }\end{array}$ & $10-50$ & $10-43$ & $50-250$ \\
\hline
\end{tabular}

Source: Commitee regulation ES n.70/2001.

Founding the European association enables free trade movement and the cooperation between single states and enterprises in the states themselves as well as within the EU. The cooperation between the enterprises within various states, the competition and the opportunity of mutual comparison required the essential steps based in facilitation of their comparison within the statements, understandability and strengthening the credibility of the accounting statements. The European comission publishes the documents to support the unification of the market within the EU in 2010 „Towards a Single Market Act“. To support the funding of SMEs the EU provides considerable resources (see mmrcr.cz where the programs of grants are listed).

The harmonisation process started slowly with the 4th EU guideline on financial statements covering accounting (Žárová M., 2004). The EU regulation 1606/2002 asks the companies whose securities are traded on the regulated market to keep accounting and prepare financial statements according to IAS/IFRS ${ }^{6}$. The purpose of financial statements is to provide truthful information. The Committee for International Standards published the International Accountancy Standards for Small and Medium Sized Enterprises in 2009 (IFRS for SME) ${ }^{7}$. Most of the EU member states allow the SME to assemble financial statements according to IFRS. This is not the case in the Czech Republic. ${ }^{8}$. The claim for comparability, clarity and reliability of financial indicators in SME accounting among the EU still remains unsolved(Kubíčková D., 2010, Albu N. -Albu C., 2010, Bohušová H., 2008, Quali A. - Paolini P., 2012).

SME are usually family enterprises, the employees are mostly family members and friends. The management is informal, via the founder's and director's as only one person. The SME are financed especially from own resources, personal investments and family loans.

\footnotetext{
${ }^{6}$ Regulation ES n. 1606/2002

${ }^{7}$ IFRS for SME, The Commitee for the International Financial Reporting Standards (IASB)

${ }^{8}$ Implementation Regulation IAS (1606/2002) in the EU and European economical space, on the 1st of July 2010.
} 


\subsection{The Czech Republic}

Accounting regulation in the Czech Repbublic is closely conected with tax obligations and the accounting units are obliged to install the analytical evidence , classification for tax purposes" (CAS001, point. 2.2.1.f) ${ }^{9}$. The rules of calculation of the tax basis are subject to many adjustments. (Mejzlík L., Artlová M., Procházka D., Vítek L., 2015). Some of adjustmmnents are not impossible to record via the analytical evidence, the special evidence of the books is also essential. In various cases it doesn't only mean to comply to the income tax law but to more laws where the definitions and calculations are different. To remain at the national regulation means in case of the claim to the international competition between the enterprises, more administrative charge in the form of management of collateral evidence in line with the IFRS.

Financial statements and accounting prepared according to CAS could not be used foregn users due to missunderstanding. A slow process of division of accounting rules and tax rules started in Czech Republic recently (Mejzlík, 1., Roe, J., Vítek, L., 2014). This process of division of the tax and accounting regulation is documented in the last adjustment of the Accounting Act that is approaching the IFRS (new statement structure, new statement rules, the accounting unit categorisation identically with ES 70/2001, excluding the extra ordinary expenses and profits, new valuation of the work in proces, the role definition of financial statements, new view of donations, etc.). To calculate the tax basis we proceed from the management results found in accounting without the influence of the international accounting standards ${ }^{10}$. This fact forces the enterprises to manage two accounting systems in case that they are for some reason obliged to assemble the financial statements according to the IFRS (Procházka, 2014).

The article 37a of the Accounting Act considers to assembling the financial statements not in accordance to this act as an delict. The financial authority doesn't manage the statistics about the given penalties for not keeping the czech accounting principles. If there is no possibility to assess the tax from the accounting, tax administrators use their own tools. Tax pyers are fined. The financial authority manages the statistics of the penalties taken, of the delay interests, but not of the division of mistakes. The tax subjects, particularly SME's focus on the tax issues required by the tax administration. This way accounting becomes a necessary reporting only for the state use. Entrepreneurs create their own statistics for their own purposes, their own estimates and their own evidence. Financial statements give only necessery information required by the CAS, sometimes even these facts are missing.

\footnotetext{
${ }^{9}$ Implementing order n. 500/2002 Code., Accounting law, The Czech Accounting Standards n. 001-024

${ }^{10} \S 23$, Law n. 586/1991 Code, Income tax.
} 
Two factors are behind the lack of publishing of useful information - one of them is the non-willingness of the enterprises to publish the data, the other one is that the state administration does nott require it.

This is how happens that even if the Accounting Act requires true and fair of the possessions, commitments and financial situation, the accountancy regarding the SME is liable to the tax laws and complying with the contriles administred by tax administrativ (L. Müllerová, M. Paseková, E. Hýblová, 2010). The closing financial statements assembled in line with IFRS provide different information than the closing financial statements assembled in line with CAS. Generally they are considered more transparent and understandable than the closing financial statements assembled in line with the national legislation. The financial statements are basis tfor assessment of the financial situation of the company and therefore the conclusions made upon the different rules can significantly vary (Kubíčková D., 2010).

The Foundation of the Commitee for International Accounting Standards thoroughly dealt with the necessity of the international comparison among SME and in 2009 the Internaional standard of accounting statements for small and medium sized enterprises was published while the decision to use these standards or not remained upon each state. Eight states within EU doesn't allow the use of the ISFR for SME, the Czech Republic is one of them ${ }^{11}$.

\section{Own Research}

The loan or fading of leasing investment prevails within the liabilities funding in the Czech Republic. The questionnaire inquiry of Ceska sporitelna, a.s., realised in 2012 among SME's proved 19 per cent interest in loan funding, the own resource funding is prevailing. Out of the target sample of 514 SME's the median would be 1 mil. CZK (The Attitude of SME to innovations and their funding, 2012).

Another funding possibility is the public support which is according to the Act $\mathrm{n}$. 47/2002 Collection. This refere to the SME's support provided by the state via the Agency for business and innovations, p.o. and the Czech-Moravian Guarantee and Development Bank, a.s. In this case the funding is guaranteed and there are usually problems with co-funding and the financial resources.

Four medium sized enterprises and three small enterprises are randomly chosen for our research. The condition for the choice of the enterprises was cross-border trade or the presence of a foreign owner. To compare the indicators only the export oriented enterprises were selected. The other condition was the data reliability- the SME's had to publish audited financial statements. The following enterprises whose closing financial statements were taken over from the business register were selected

${ }^{11}$ www.kacr.cz/ifrs, (source dated 1.7.2010) 
to this sample : ZK-Termochem, s.r.o., PETROF, spol. s r.o., ARIES, a.s., SOPO s.r.o., Konstruktpol s.r.o., Geis Parcel CZ s.r.o. a 4isp s.r.o. The selected enterprises are mainly export- oriented, most of them are possessed by a Czech owner, two of them (Geis Parcel CZ and 4isp) are ewned by a foreign owner. The selected financial statements of the above listed enterprises were assembled to the 31 st of December 2015.

All of the selected companies manage their accounting in line with CAS. The data regarding the long-term debts and commitments are taken over form the Balance sheet and Notes. The farther necesery transformation concerned the adjustment of the long-term receivables and debts and exclusion of the exchange rate differences:

- The long-term debts and receivables were re-counted into the present value to the date of the closing financial statement. Considering that before the start of the accounting period the re-count to the value related to the accounting period was realised, the interest rate 4 per cent and 2 per cent inflation.

- The exchange rate losses and exchange rate profits were excluded out of the Profit and Loss statement.

- The selected enterprises are mainly export-oriented. Export represents a significant part of their production.

Table 2: Small enterprises, results taken over from the 2015 closing financial statements in thousands of CZK.

\begin{tabular}{|l|l|l|l|l|l|l|}
\hline \multirow{2}{*}{ Item } & 4isp s.r.o. & \multicolumn{3}{l|}{ Geis Parcel CZ s.r.o. } & \multicolumn{2}{l|}{ Konstruktpol s.r.o. } \\
\cline { 2 - 8 } & CAS & IFRS & CAS & IFRS & CAS & IFRS \\
\hline EBIT & +990 & +1001 & +30417 & +32089 & +9374 & +11130 \\
\hline Indebtness & 0,84 & 0,89 & 0,31 & 0,31 & 0,45 & 0,45 \\
\hline Liquidity & 3,30 & 3,31 & 2,67 & 2,67 & 2,54 & 2,48 \\
\hline ROE & 0,15 & 0,15 & 0,13 & 0,14 & 0,27 & 0,32 \\
\hline ROA & 0,025 & 0,025 & 0,092 & 0,097 & 0,14 & 0,17 \\
\hline Tax & 188 & 190 & 5779 & 6097 & 1762 & 2115 \\
\hline
\end{tabular}

Source: own calculation 
Table 3: Medium sized enterprises, results taken over from the 2015 closing financial statements in thousands CZK.

\begin{tabular}{|l|l|l|l|l|l|l|l|l|}
\hline \multirow{2}{*}{ Položka } & \multicolumn{2}{l}{ SOPO s.r.o. } & \multicolumn{2}{l|}{ Aries a.s. } & \multicolumn{2}{l|}{ Petrof s.r.o. } & \multicolumn{2}{l|}{$\begin{array}{l}\text { ZK-Termochem } \\
\text { s.r.o. }\end{array}$} \\
\cline { 2 - 10 } & ČÚS & IFRS & ČÚS & IFRS & ČÚS & IFRS & ČÚS & IFRS \\
\hline \multirow{2}{*}{ EBIT } & +9721 & +9814 & - & -452 & +9633 & +11804 & +53393 & +57609 \\
\hline Indebtness & 0,59 & 0,74 & 0,81 & 0,82 & 0,17 & 0,18 & 0,28 & 0,28 \\
\hline Liquidity & 5,16 & 5,16 & 1,01 & 0,99 & 11,78 & 11,78 & 3,45 & 3,45 \\
\hline ROE & 0,27 & 0,27 & 0 & 0 & 0,03 & 0,04 & 0,34 & 0,36 \\
\hline ROA & 0,078 & 0,079 & - & - & 0,024 & 0,029 & 0,119 & 0,129 \\
\hline \multirow{2}{*}{ Tax } & 1847 & 1865 & 0 & 0 & 1830 & 2243 & 10145 & 10946 \\
\hline
\end{tabular}

\section{Source: own calculation.}

From the above charts $\mathrm{i}$ tis evident that there are differences between the closing financial statements assembled in line with CAS and according to IFRS. Even if it concerns only selected indicators written in the statements and in notes (it's necessary to think about the facts and reasons whose publication is not required by the Czech rules, for example high supplies that are essential to suppport the functioning of the entreprise in case of for example the complaint and reparations while it's not clear if it concerns the long-term advance provided for example on material and that these supplies are not stated in the long-term assets statement, the commitments after the due date, finance and operative leasings) significant differences are evident, they are mainly caused by the exchange rate of the currency.

The EBIT indicator is in all cases significantly higher using the statements in line with the IFRS. We can see a relevant difference looking at the Aries, a.s. company where the EBIT is 32 per cent higher when assembling the statement in line with IFRS on contrary to the ČUS, within the company PETROF, s.r.o. it is 22 per cent and the company Konstruktpol 18 per cnet. It means that there are losses created by the exchange rate of the Czech crown to the foreign currency and that these losses harm the enterprise in case of its evaluation and distort the data regarding its financial situation. They distort the basis to evaluate the enterprise in case they need the loan or leasing.

In 2015 the exchange rate was not advantageous for the export-oriented organisations) It used to be solved by temporary accounts of assets and liabilities, currently the exchange rate differences are a part of the tax admissible profits and expenses.There is no doubt that the tax public is still engaged in this problematic. A 
possible solution is a translation to the national currency to the closing date of financial statement for the statistics purposes and to set the tax basis (Act $n$. 586/1992 Code., income tax, \$38). Other indicators do not show such significant differences because of the short term - one year.There are some differences due to the adjustment of the long-term liabilities and receivables though . The indebtness indicator is higher in all cases. The liquidity indicator doesn't change for most of the companies. According to the Czech rules the assets are valued to their real value using the adjustments always downwards, but the liabilities remain at their historical value, so the liquidity is not significantly skewed. According to the CAS the liabilities are not re-valued to the current value, the indicator of the indebtness is therefore higher.

Thanks to the greater EBIT when assembling the closing financial statements in line with IFRS the states in the profitability of the own capital - ROE and mainly the profitability of the assets - ROA, also the higher data taken over from the closing financial statements modified to the IFRS.

When calculating the profitability we use the gain before taxation and interests (EBIT). The reason is that the interests can be recognized in the Czech accounting as well as in the tax system as a part of the acquisition price of the investment or to comprise them into the expenses in time of their origin. This depends on the decision of accounting unit and the Czech tax law recognized this attitude. In case the interests do not participate on the acquisition price of the possession from the tax point of view and they are recognized as an expense, the tax duty is lower, if the interests participate on the acquisition price of the possession, the tax duty is higher. That is the mason why there is also the tax duty in the Czech Republic calculated in currently valid conditions despite the accounting being managed in line with the IFRS or CAS. Both options can be solved using the operative evidence.

\section{Conclusions}

The reaserch study used an indikative sample of 7 enterprises, randomly chosen out of the export-oriented enterprises. When evaluating the solvency of the client using the mentioned indicators, the client would more easily obtain the loan while assembling the closing financial statements in line with the IFRS than the client who assembles the closing financial statements in line with CAS. The relusting indicators are more favorable when using the IFRS. With the current exchange rate of the Czech crown and the recalculation of commitments and liabilities to the current value enabling the assembly of the statements in line with the IFRS for SME the gain before taxation and interests (EBIT) would be significantly higher for three enterprises and higher for all the enterprises in the sample. The evaluation indicators to gain the financial support taken over out of the closing financial statements assembled in line with the IFRS show better results than the evaluation indicators taken over from the closing financial statements assembled in line with CAS. The 
profitability of the own capital is higher at almost every sample, the profitability of the assets is significantly higher.

The financial institutions are particularly interested in return of their invested funds and the fee for the invested funds - interest revenue. Before evaluation of the invested funds they use the mentioned indicators (Liquidity, ROE, ROA, indebtedness) that in case of using the closing financial statements in line with the IFRS provided much better indicators for the SMEs in this sample.

In case of bank loans the maximum guarantee is 80 per cent of the required loan and 50 per cent of the gain invested into the planned investment (www.businessinfo,cz/cs/clanky/nabídka-sluzeb-ceskomoravske). The SMEs are frequently unable to reach these conditions. The solution to help the funding and SME's business are the commensurable data with other states and offering understandable and acceptable data to potencial investors. Until this time the SMEs will be left to the foreign funding within avaliable within the Czech Republic or to compare the expenses on their accounting transformation to the form comprehensible to the foreign investor and to the provided financial support.

\section{References:}

Albu, C., Albu, N. 2013. IFRS for SMEs in Europe - Lessons for a Possible Implementation in Romania, 5th WSEAS International Comference on Economy and Management Transformation (volume II), ISBN 978-960-474-241-7, 659-663.

Bohušová, H. 2008. Accounting Harmonisation and Aplication IAS/IFRS: Selected IAS/IFRS within Czech Enterprise Conditions, Prague, ASPI, ISBN 798-80-7357366-9.

Dvořáková, D. 2008. Financial Accounting and Reporting According to the International Standards IFRS, Computer Press, a.s., ISBN 978-80-251-1950-1.

Giannarakis, G. 2016. The Challenges of Corporate Social Responsibility Assessment Methodologies. International Journal of Economics and Business Administration, 4(1), 39-55.

Helisek, M. 2016. Supporting Small and Medium-sized Enterprises in Preparing for the Euro Adoption in the Czech Republic. European Research Studies Journal, 19(4), 27-41.

IASB, 2009. London, International Financial Reporting Standards (IAS,IFRS).

Krchnivá, K. 2016. The Impact of Instalation of the Common Consolidated Corporate Tax Base to the Czech Republic Budget, Doctoral thesis, Mendel University.

Kubíčková, D. 2010. Reporting According to the IAS/IFRS a Bankrupt Models, Ostrava, 5th International Conference Management and models of financial risks VŠB-TU Ostrava.

Liapis, K., Thalassinos, I.E. 2013. A Comparative Analysis for the Accounting Reporting of "Employee Benefits" between IFRS and other Accounting Standards: A Case Study for the Biggest Listed Entities in Greece. International Journal of Economics and Business Administration, 1(1), 91-116.

Mejzlík, L., Artlová, M., Procházka, D., Vítek, L. 2015. Implementation of the International Standards of the Accountancy Reporting in the Czech Republic and its influence on 
the Enterprise Taxation, Political economy, 7, $811-831$.

Mejzlík, L., Vítek, L., Roe, J. 2014. Adjustments to the Accounting Profit in Determination the Income Tax Base: Evolution in the Czech Republic,European Financial and Accounting Journal, 9(99), 4-24.

Mullerová, L., Paseková, M., Hýblová, E. 2010. The Analysis of the Accounting and Reporting Development of the Small and Medium Sized Enterprises, The Czech financial and Accounting Journal, 5(1), 20-36.

Quali, A., Paolini, P. 2012. How is the IFRS for SME accepted in the European context? An analysis of the homogenity among European countries, users and preparers in the European commission questionnaire, Advances in Accounting, incorporating Advvances in International Accounting, 28, 147-156.

Procházka, D. 2014. The IFRS as Tax Base: Potential Impact on a Small Open Economy, European Financial and Accounting Journal, 9(4), 59-75.

Sokol, J. 2015. Power, Money and Law, Vyšehrad, ISBN 798-80-7429-638-3.

Thalassinos, I.E. and Kiriazidis, T. 2003. Degrees of Integration in International Portfolio Diversification: Effective Systemic Risk. European Research Studies Journal, 6(1-2), 119-130.

Thalassinos, I.E. and Liapis, K. 2014. Segmental financial reporting and the internationalization of the banking sector. Chapter book in, Risk Management: Strategies for Economic Development and Challenges in the Financial System, (eds), D. Milos Sprcic, Nova Publishers, 221-255, ISBN: 978-163321539-9; 978163321496-5.

Thalassinos, I.E., Liapis, K. and Thalassinos, E.J. 2014. The role of the rating companies in the recent financial crisis in the Balkan and black sea area. Chapter book in Economic Crisis in Europe and the Balkans, 79-115, Contributions to Economics, Springer International Publishing, DOI: 10.1007/978-3-319-00494-5-6.

Thalassinos, I.E. 2008. Trends and Developments in the European Financial Sector. European Financial and Accounting Journal, 3(3), 44-61.

Thalassinos, I.E. and Dafnos, G. 2015. EMU and the process of European integration: Southern Europe's economic challenges and the need for revisiting EMU's institutional framework. Chapter book in Societies in Transition: Economic, Political and Security Transformations in Contemporary Europe, 15-37, Springer International Publishing, DOI: 10.1007/978-3-319-13814-5_2.

Valach, J. 2010. Investment Decisions and Longterm Funding, Ekopress, ISBN 978-8086929-71-2.

Žárová, M. 2004. VŠE, Regulation of the European Accounting out of the International Harmonisation Point of View, 1, Acta Oecomomica Pragensia, 12-21. 